\title{
STATISTIK LUAS DAERAH AKTIF MATAHARI DAN PERUBAHANNYA
}

\author{
Mohamad Dena Nugraha ${ }^{1, a)}$, Rhorom Priyatikanto ${ }^{2, b)}$, Judhistira Aria Utama ${ }^{1, c)}$ \\ ${ }^{1}$ Departemen Pendidikan Fisika, Fakultas Pendidikan Matematika dan Ilmu Pengetahuan Alam, Universitas \\ Pendidikan Indonesia. \\ ${ }^{2}$ Pusat Sains Antariksa, Lembaga Penerbangan dan Antariksa Nasional Jl. Dr. Djundjunan 133, Bandung, \\ 40173, Indonesia.
}

Email: a)arzein12@ @ student.upi.edu, ${ }^{\text {b) }}$ rhorom.priyatikanto@lapan.go.id, ${ }^{c}$ j.aria.utama@upi.edu

\begin{abstract}
Abstrak
Luas daerah aktif Matahari merupakan salah satu indeks aktivitas Matahari yang berperan penting karena berkaitan dengan indeks yang lain maupun dengan flare yang dapat terjadi. Oleh karena itu, penelitian ini dilakukan untuk memahami variabilitas, distribusi, maupun pola perubahannya yang dapat berkaitan dengan kejadian flare. Arahnya adalah untuk memprediksi flare berdasarkan luas daerah aktif. Data grup bintik Matahari dari siklus ke-23 dan 24 dianalisis untuk keperluan tersebut dan beberapa temuan dapat dilaporkan. Pertama, daerah aktif berukuran besar cenderung memiliki kompleksitas yang lebih tinggi, dilihat dari kelas Zurich-nya. Ke dua, distribusi luas daerah aktif mengikuti fungsi eksponensial. Ke tiga, distribusi perubahan harian luas total daerah aktif hampir simetris di sekitar 0 dengan simpangan baku $\sigma_{\mathrm{h}}=193,95$ satuan luas. Untuk daerah aktif yang sama, diperoleh $\sigma_{\mathrm{AR}}=60,789$. Statistik ini dapat digunakan sebagai acuan evaluasi kondisi aktivitas Matahari. Selanjutnya, dikonfirmasi pula bahwa daerah aktif berukuran besar lebih banyak menghasilkan flare meski nilai korelasi antara kedua variabel tidak terlalu besar $(\mathrm{R}=0,503)$. Hubungan nilai luas daerah aktif Matahari dengan kejadian flare ini dapat dijadikan acuan untuk memprediksi kejadian flare yang dapat berdampak terhadap kehidupan di Bumi.
\end{abstract}

Kata-kata kunci: Aktivitas Matahari, Luas daerah aktif, Statistik, Flare.

\begin{abstract}
The area of an active region is one of the Solar's activity indices that plays an important role because it is related to other indices and flares that can occur. Therefore, this research was conducted to understand the variability, distribution and the pattern that can be associated with solar flares. The objective is to predict flares based on the area of an active region. Sunspots group data from the 23rd and 24th cycles are analyzed for this purpose and some findings can be reported. First, large active regions tend to have higher complexity as seen from the Zurich class. Second, the distribution of the area follows the exponential function. Third, the distribution of daily changes in the total area of the active region is almost symmetrical at around 0 with a standard deviation $\sigma_{\mathrm{h}}=193.95$ units of area. For the same active region, $\sigma_{\mathrm{AR}}=60,789$ is obtained. This statistics can be used as a reference for evaluating solar activity conditions. Furthermore, it was also confirmed that large active regions produce more flares even though the correlation value between the two variables is not too high $(\mathrm{R}=0.503)$. The relationship between the value of the area of solar active regions and the incidence of flares can be used as a reference to predict the incidence of flares that can have an impact for life on Earth.
\end{abstract}

Keywords: Solar activity, Active region area, Statistic, Flare. 


\section{PENDAHULUAN}

Luas daerah aktif Matahari ini menjadi salah satu parameter yang penting untuk diteliti dan dipertimbangkan dalam prakiraan cuaca antariksa karena dapat merepresentasikan kuat medan magnet lokal di permukaan Matahari. Luas daerah aktif juga mempengaruhi iradiansi total Matahari (Total Solar Irradiance) secara signifikan [1][2]. Luas daerah aktif berkaitan dengan bentuk lain dari aktivitas Matahari yakni frekuensi kejadian flare yang kadang-kadang dapat disertai oleh semburan partikel energetik dari CME (Coronal Mass Ejection). Partikel dari flare maupun CME tersebut dapat mencapai Bumi dan berdampak bagi kehidupan di Bumi terutama pada daerah lintang tinggi maupun di lingkungan sekitar Bumi (berdampak terhadap keselamatan para astronot dan teknologi satelitnya). Dengan alasan ini penelitian luas daerah aktif Matahari menjadi salah satu parameter yang penting untuk diteliti dan dipertimbangkan dalam prakiraan cuaca antariksa. Penggunaan data flare yang direkam oleh Geostationary Operational Environment Satellite (GOES) sepanjang tahun 1996 hingga 2010 untuk menghitung frekuensi kejadian flare dan mengaitkannya dengan kelas McIntosh, bintik Matahari dan luasnya dapat dijumpai dalam [3]. Secara statistik, mereka menyimpulkan bahwa daerah aktif yang mengalami pertambahan luas memiliki probabilitas flare yang lebih tinggi [3]. Probabilitas kejadian CME juga berkaitan dengan perubahan luas daerah aktif Matahari [4]. Terdapat pula hubungan antara luas daerah aktif atau eruptif dengan energi total flare yang dilepaskan sepanjang kemunculannya di piringan Matahari [5].

Dalam penelitian ini telah dilakukan analisis total luas daerah aktif Matahari sepanjang siklus Matahari ke-23 dan siklus ke-24. Keluaran yang diharapkan dari studi ini adalah diperolehnya pola variabilitas luas daerah aktif dengan variabel bintik yang lain, seperti kelas Zurich, selain batas kuantitatif dari lima kelas perubahan yang didefinisikan sebagai: menurun, agak menurun, tetap, agak naik, dan naik. Kuantisasi dari kelima kelas tersebut telah dilakukan untuk fluks sinar-X, fluks radio $10 \mathrm{~cm}$, dan bilangan bintik Matahari [5], sementara kuantisasi untuk luas daerah aktif belum dilakukan karena bergantung pada rekaman data yang berbeda. Untuk mendapatkan batasan tersebut, distribusi perubahan harian dimodelkan dengan fungsi Gaussian, di mana deviasi digunakan sebagai acuan batas kelas. Diperolehnya hubungan antara luas daerah aktif dengan flare yang terjadi adalah hasil lain yang juga diharapkan, yang selanjutnya dapat dimanfaatkan dalam upaya memprediksi flare yang akan terjadi.

\section{DATA DAN METODE}

\section{Data}

Data yang digunakan dalam studi ini adalah parameter daerah aktif yang dirangkum dalam Solar Region Summary (SRS) yang dihasilkan oleh National Oceanic and Atmospheric Administration (NOAA) dan diakses melalui ftp://ftp.swpc.noaa.gov/pub/warehouse/. Data mencakup siklus Matahari ke-23 (1996 hingga 2007) dan siklus ke-24 yang sedang berlangsung (2008 hingga 2017) dengan jumlah data keseluruhan yaitu 33.234 data. Sebagai pembanding, rekaman bilangan bintik Matahari diperoleh dari Sunspot Index and Long-term Solar Observations - Solar Influences Data Analysis Center (SILSO - SIDC) (http://sidc.oma.be/silso/datafiles).

Hanya daerah aktif yang berada di antara $-70^{\circ}$ hingga $+70^{\circ}$ bujur heliografis saja yang ditelaah karena efek proyeksi membuat penentuan parameter daerah aktif di tepi piringan Matahari menjadi sulit dan parameter yang dihasilkan pun menjadi tidak akurat. Hal ini dapat dilihat dari nilai rata-rata ternormalisasi yang menyimpang jauh dari nol.

\section{Metode}

Metode statistika deskriptif digunakan untuk menelaah data yang ada. Sejumlah parameter dasar seperti nilai rata-rata, simpangan baku, kemiringan (skewness), serta keruncingan (kurtosis) distribusi ditentukan dengan saksama. Fungsi distribusi fundamental seperti fungsi Gaussian dan fungsi eksponensial juga dicocokkan dengan data untuk memahami karakteristiknya. Persamaan dasar yang digunakan dirangkum dalam TABEL 1. 
TABEL 1. Persamaan dasar yang digunakan dalam studi ini.

\begin{tabular}{|c|c|c|}
\hline No & Persamaan & Keterangan \\
\hline 1. & $\begin{array}{l}\text { Nilai rata-rata ternormalisasi } \\
\text { Norm.Value }=\frac{\langle A\rangle}{\left\langle A_{0}\right\rangle}-1\end{array}$ & $\begin{array}{l}\text { Dengan }\langle A\rangle \text { menyatakan rata-rata luas pada bujur tertentu, } \\
\text { dan }\left\langle\mathrm{A}_{0}\right\rangle \text { pada bujur } 0^{\circ}\end{array}$ \\
\hline 2. & $\begin{array}{l}\text { Fungsi distribusi Gaussian } \\
n(x, \mu, \sigma)=\frac{1}{\sqrt{2 \pi \sigma}} e^{-\left(\frac{1}{2}\right)\left(\frac{x-\mu}{\sigma}\right)^{2}}\end{array}$ & $\begin{array}{l}\text { Distribusi Normal mempunyai kaitan kuat dengan ukuran } \\
\text { sampel }(n) \text { dengan menggambarkan distribusi data }(x) \text { yang } \\
\text { diparameterisasi oleh nilai rata-rata }(\mu) \text { dan simpangan baku } \\
(\sigma) \text {. }\end{array}$ \\
\hline 3. & $\begin{array}{l}\text { Fungsi kerapatan probabilitas } \\
f(x)=\frac{1}{\sigma \sqrt{2 \pi}} e^{\frac{(x-\mu)^{2}}{2 \sigma^{2}}}\end{array}$ & $\begin{array}{l}\text { Probability Density Function menyatakan nilai probabilitas } \\
\text { dari setiap kejadian } x \text { dan dituliskan dengan } f(x) \text {. }\end{array}$ \\
\hline 4. & $\begin{array}{l}\text { Skewness } \\
S k=\frac{\mu-M o}{\sigma}\end{array}$ & $\begin{array}{l}\text { Merepresentasikan tingkat kemiringan distribusi. } S k \\
\text { merupakan Skewness dan } M o \text { menyatakan nilai modus dari } \\
\text { data. }\end{array}$ \\
\hline 5. & $\begin{array}{l}\text { Kurtosis } \\
K=\alpha_{4}=\frac{(x-\mu)^{4}}{n \sigma^{4}}\end{array}$ & $\begin{array}{l}\text { Merepresentasikan keruncingan distribusi data atau derajat } \\
\text { kepuncakan suatu distribusi. } K=\alpha_{4} \text { merupakan Kurtosis dan } n \\
\text { menyatakan jumlah data. }\end{array}$ \\
\hline 6. & $\begin{array}{l}\text { Perubahan harian } \\
\frac{\Delta f}{\Delta t}=\frac{f_{2}-f_{1}}{t_{2}-t_{1}}\end{array}$ & $\begin{array}{l}\text { Perubahan harian luas daerah aktif Matahari dihitung dengan } \\
\text { persamaan ini, dengan } f \text { merupakan luas daerah aktif Matahari, } \\
\text { dan } t \text { merupakan hari. }\end{array}$ \\
\hline
\end{tabular}

\section{HASIL DAN PEMBAHASAN}

Setelah melalui pemeriksaan kualitas data, diperoleh hanya data yang berada di antara koordinat HGS -70 hingga 70 derajat sebagai data terbaik dan data tersebutlah yang selanjutnya digunakan dalam penelitian ini. Data yang telah terkoreksi dan dinyatakan baik untuk diolah lebih lanjut berjumlah 28.759 data.

Pola Variabilitas Luas Daerah Aktif Matahari

Perbanding Luas Daerah Aktif dan Flare dengan Kelas Zurich

Dalam studi ini, Penulis menggunakan kelas Zurich dari klasifikasi McIntosh yang ada dengan pertimbangan dirasa cukup dalam menggambarkan luas daerah aktif. Selanjutnya dibuat perbandingan flare denngan kelas tersebut agar dapat diketahui hubungan flare dengan kelasnya maupun hubungan flare dengan luas daerah aktif Matahari. Grafik keluarannya berupa kelas Zurich yang diurutkan berdasarkan kompleksitasnya, yaitu dari A, B, H, C, D, E, dan F yang akan menjadi variabel x. Grafik yang diperoleh berupa grafik Box and Whisker dengan Box-nya berupa nilai kuartil 1, median, dan kuartil 3 serta Whisker-nya berupa nilai minimum dan maksimum dari nilai luas daerah aktif berdasarkan setiap kelas Zurich-nya sebagaimana ditunjukkan dalam GAMBAR 1. 


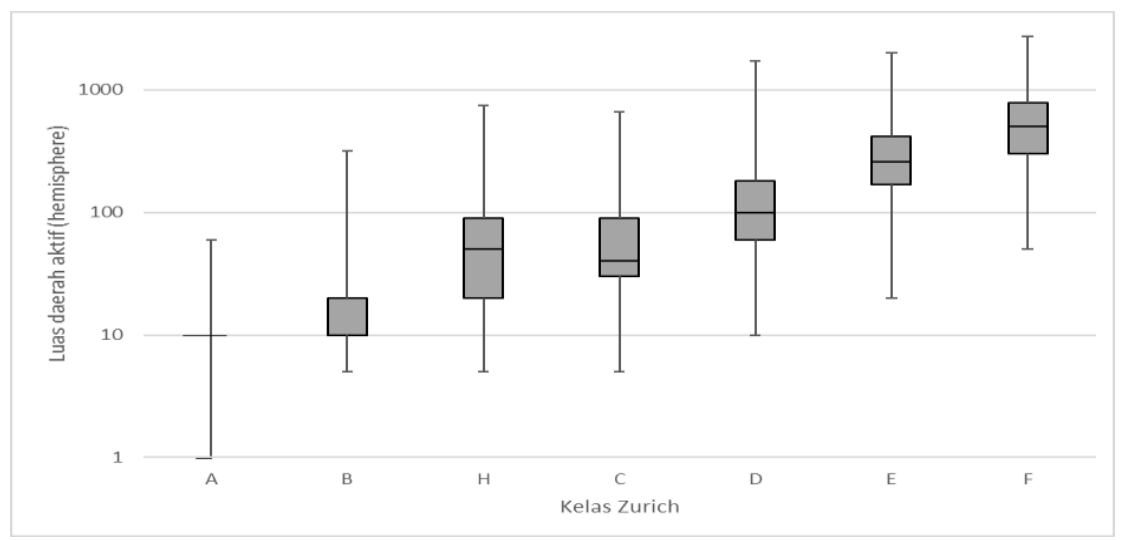

GAMBAR 1. Luas daerah aktif terhadap Zurich

Dalam GAMBAR 1 terlihat bahwa nilai luas daerah aktif untuk setiap kelas mengalami kenaikan yang menandakan adanya hubungan linier antar keduanya. Kelas Zurich menandakan kondisi perkembangan grup bintik Matahari, yaitu dari ukuran, bentuk, dan kerapatan bintiknya, yang berarti bahwa semakin kompleks grup bintik Matahari maka luas daerah aktifnya pun semakin besar. Terlihat pula dari GAMBAR 1 bahwa nilai median, serta nilai maksimal dari kelas $\mathrm{H}$ ke $\mathrm{C}$ cenderung menurun. Hal ini dikarenakan kelas Zurich $\mathrm{H}$ merupakan sebuah grup bintik unipolar dengan penumbra yang biasanya merupakan sisa dari grup bintik bipolar. Sementara, kelas C merupakan sebuah grup bintik bipolar dengan penumbra pada salah satu bintiknya dan biasanya bintik $\mathrm{p}$ (preceding)-nya terbesar. Dengan demikian, kelas Zurich $\mathrm{H}$ maupun $\mathrm{C}$ kompleksitas grupnya tidak terlalu berbeda jauh dan kedua kelas tersebut hampir memiliki luas daerah aktif yang sama. Dalam GAMBAR 2 ditunjukkan data flare yang terjadi berdasarkan kelas Zurich-nya.

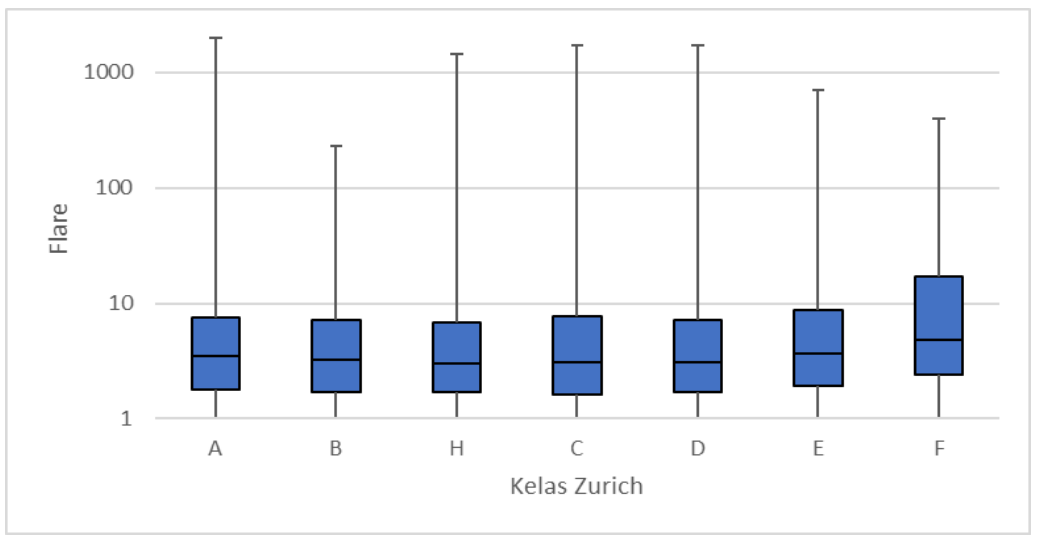

GAMBAR 2. Grafik nilai indeks flare terhadap kelas Zurich

Menurut GAMBAR 2, jumlah flare yang terjadi tidak jauh berbeda untuk setiap kelas Zurich-nya. Hanya saja untuk nilai flare kuartil 1, median, kuartil 3 serta reratanya, kelas F terlihat lebih tinggi mengingat kelas ini lebih kompleks daripada kelas-kelas yang lain. Selain itu, nilai maksimum dari setiap kelas juga terlihat berbeda satu dengan lainnya dan nilai tertinggi dijumpai dimiliki oleh kelas A, yaitu flare kelas X20 (sekitar 2 miliwatt $/ \mathrm{m}^{2}$ ), yang menandakan bahwa kompleksitas yang rendah sekalipun tetap berpeluang menghasilkan terjadinya flare yang besar meskipun jarang terjadi. Dapatlah dipahami bahwa nilai rerata maupun nilai terbesar lainnya tetap terdapat di kelas F (kelas dengan kompleksitas tertinggi).

\section{Distribusi Luas Daerah Aktif Matahari}

Dalam GAMBAR 3 ditunjukkan histogram distribusi luas daerah aktif Matahari terhadap frekuensi kemunculannya. Terlihat bahwa dalam rentang nilai $\log \mathrm{A}=1,0-2,4$ frekuensinya 
berfluktuasi, namun untuk $\log \mathrm{A}>2,4$ cenderung menurun. Frekuensi luas daerah aktif Matahari terbesar berada di rentang $\log \mathrm{A}=1,0-1,2$ dengan jumlah sebanyak 4738. Berdasarkan GAMBAR 3 , telah dibangun relasi matematis yang menunjukkan hubungan eksponensial antara luas daerah aktif dengan frekuensinya berupa $y=4,352 \mathrm{e}^{-0.055 x}$ dengan nilai korelasi $\mathrm{R}=0,8057$ dan koefisien determinasinya $\mathrm{R}^{2}$ sebesar 0,6491 .

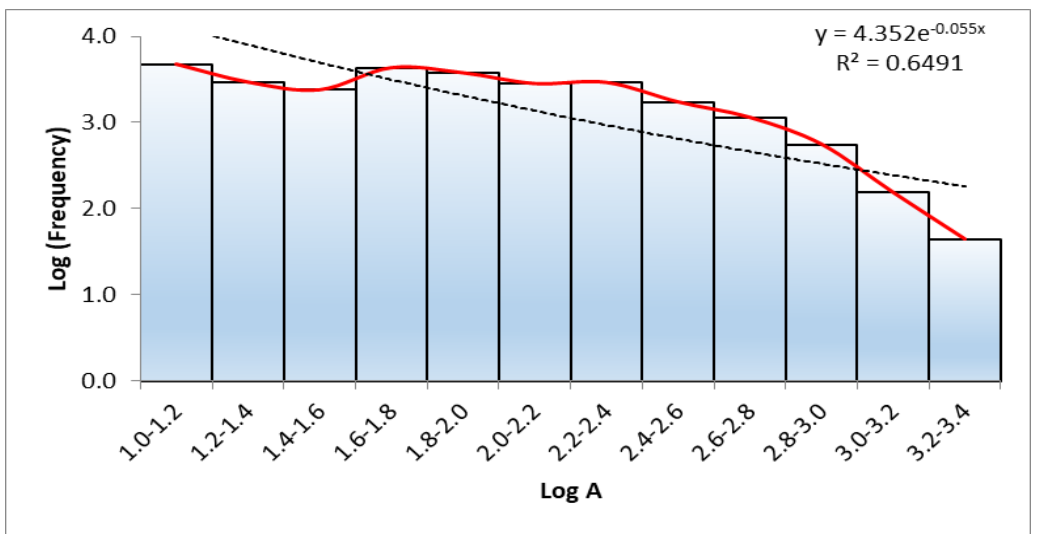

GAMBAR 3. Grafik log luas daerah aktif terhadap log frekuensi

\section{Pola Perubahan Harian Luas Daerah Aktif Matahari dan Distribusi Normal \\ Perubahan harian luas daerah aktif dan perubahan harian luas daerah aktif tiap AR}

Distribusi perubahan luas daerah aktif Matahari secara harian dan menurut daerah aktifnya ditunjukkan dalam GAMBAR 4. Berdasarkan GAMBAR 4 pola perubahan luas daerah aktif cukup sesuai dengan distribusi normal, meskipun sayap fungsi distribusi normal terlihat lebih lebar dibandingkan histogram perubahan luas daerah aktif Matahari harian maupun perubahan luas daerah aktif untuk tiap nomor daerah aktifnya (AR: Active Region). Selain itu di sekitar nilai 0 juga terdapat spike yang jauh lebih tinggi dibandingkan fungsi distribusi normalnya. Tingginya nilai di sekitar perubahan luas 0 mengindikasikan banyaknya bintik yang tidak berubah atau perubahan hariannya dan perubahan untuk tiap daerah aktifnya kecil. Hal ini terlihat pula dari nilai rerata untuk perubahan harian sebesar 2,36 yang dalam skala di sumbu-X terlalu kecil sehingga berada di sekitar nilai 0 sama seperti nilai median dan modusnya. Demikian pula untuk perubahan luas menurut daerah aktifnya memiliki kecenderungan sama. Nilai reratanya sebesar 2,048 sangat kecil dibandingkan skala di sumbu-X sehingga berada di sekitar nilai 0 seperti nilai median dan modusnya, yang dimaknai bahwa bintik dengan nomor AR yang sama cenderung tidak berubah luasnya.

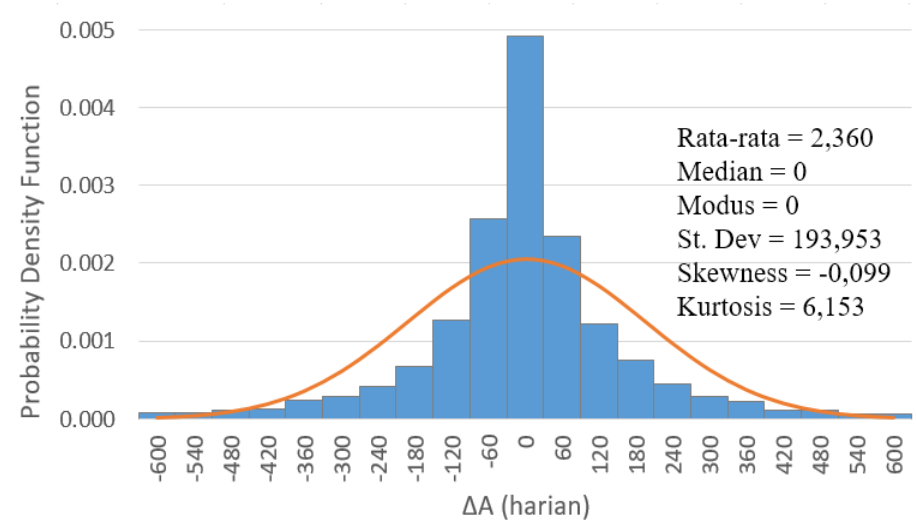

(a)

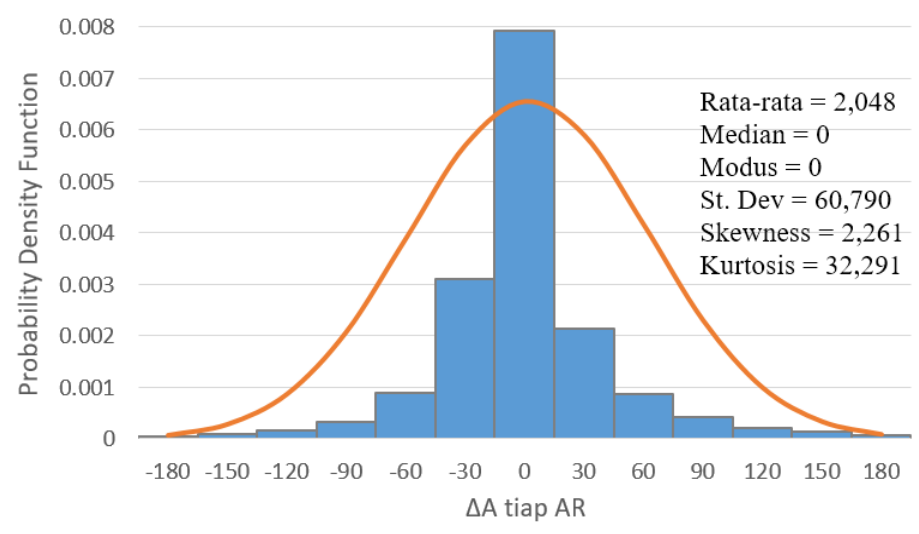

(b)

GAMBAR 4. Grafik (a) perubahan luas daerah aktif harian terhadap PDF dan grafik (b) perubahan harian luas daerah aktif tiap AR terhadap PDF. Grafik garis berwarna merah muda merupakan distribusi normalnya. 
Berdasarkan nilai skewness kedua kurva, kurva hasil pencocokan untuk perubahan harian luas daerah aktif Matahari lebih condong ke kiri, sementara kurva perubahan luas daerah aktif untuk tiap daerah aktifnya condong ke arah kanan. Sementara menurut nilai kurtosis yang dihasilkan kurva perubahan harian luas daerah aktif Matahari kurang runcing bila dibandingkan dengan kurva perubahan luas untuk tiap daerah aktif.

\section{Kelas Perubahan}

Berdasarkan GAMBAR 4, dapat disusun batasan kelas perubahan. Bila jumlah kasus dalam setiap kelas tersebut dianggap sama, misalnya 20\% kasus turun, 20\% kasus agak turun dan seterusnya, maka batas kelas dapat ditentukan sesuai dengan luas daerah aktif di bawah kurva distribusi normal. GAMBAR 5 berikut ini menunjukkan ilustrasi pembagian kelas sesuai dengan fungsi distribusi normal.

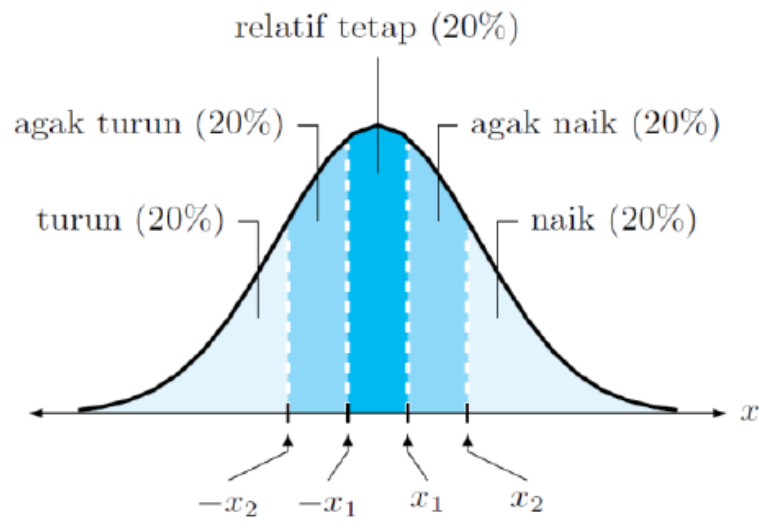

GAMBAR 5. Ilustrasi pembagian kelas sesuai distribusi normal (Sumber: Priyatikanto, 2015)

Mengikuti pekerjaan dalam [5], kuantisasi kelas perubahan dapat disusun sebagai berikut:

- Menurun : berada pada rentang $(\Delta \mathrm{f} / \Delta \mathrm{t}-\mu) \leq-\mathrm{x}_{2}$, di mana $\mathrm{x}_{2}=0,85 \sigma$

- Agak menurun : berada pada rentang $-\mathrm{x}_{1} \geq(\Delta \mathrm{f} / \Delta \mathrm{t}-\mu) \leq-\mathrm{x}_{2}$, di $\operatorname{mana} \mathrm{x}_{1}=0,25 \sigma$

- Tetap : berada pada rentang $-\mathrm{x}_{1} \geq(\Delta \mathrm{f} / \Delta \mathrm{t}-\mu) \leq \mathrm{x}_{1}$

- Agak naik : berada pada rentang $\mathrm{x}_{1} \geq(\Delta \mathrm{f} / \Delta \mathrm{t}-\mu) \leq \mathrm{x}_{2}$

- Naik : berada pada rentang $(\Delta \mathrm{f} / \Delta \mathrm{t}-\mu) \geq \mathrm{x} 2$

Berdasarkan kuantisasi kelas tersebut, dapat dihitung batas kelasnya menggunakan standar deviasi yang diperoleh. Batas kelas dan rentang setiap kelas perubahannya ditunjukkan dalam TABEL 2. Dapat dilihat dalam TABEL 2 rentang kelas perubahan dari GAMBAR 4 dengan setiap kelas mewakili $20 \%$ dari grafik lonceng yang terbentuk. Berdasarkan kuantisasi kelas yang dihasilkan, bagian tertinggi dalam GAMBAR 4 berada di kelas perubahan 'Tetap', yang menandakan bahwa luas daerah aktif Matahari cenderung tetap setiap harinya atau hanya memiliki perubahan luas yang kecil.

TABEL 2. Nilai batas kelas dengan kelas perubahan

\begin{tabular}{lccccccc}
\hline \multirow{2}{*}{$\begin{array}{l}\text { Perubahan } \\
\text { Luas }\end{array}$} & \multicolumn{3}{c}{ Batas Kelas } & \multicolumn{4}{c}{ Kelas Perubahan } \\
\cline { 2 - 7 } & $x_{1}$ & $x_{2}$ & Menurun & $\begin{array}{c}\text { Agak } \\
\text { menurun }\end{array}$ & Tetap & Agak naik & Naik \\
\hline Harian & 48 & 165 & {$[-\infty,-165]$} & {$[-165,-48]$} & {$[-48,48]$} & {$[48,165]$} & {$[165, \infty]$} \\
Tiap AR & 15 & 52 & {$[-\infty,-52]$} & {$[-52,-15]$} & {$[-15,15]$} & {$[15,52]$} & {$[52, \infty]$} \\
\hline
\end{tabular}

\section{Hubungan Empiris Antara Luas Daerah Aktif dan Flare yang Dihasilkan}

GAMBAR 6 menunjukkan banyaknya flare yang terjadi di daerah aktif yang tidak luas dan cenderung acak. Terlihat adanya daerah yang lebih rapat dan menandakan seringnya terjadi flare, yaitu di daerah yang dibatasi garis hijau putus-putus. Garis merah putus-putus merupakan gradien garis yang menunjukan kelinierannya. Hasil ini sama seperti yang diperoleh Sammis (2000) yang memperoleh hubungan linier antara luas daerah aktif dengan flare [6]. Persamaan garis yang diperoleh adalah $y=0,9656 x-1,986$ dengan koefisien korelasi dan determinasi masing-masing 
adalah $\mathrm{R}=0,503$ dan $\mathrm{R}^{2}=0,253$. Nilai korelasi dan determinasi ini menunjukan bahwa total harian luas daerah aktif dengan flare maksimumnya berkorelasi 50,3\% dan nilai flare maksimum yang dipengaruhi total harian luas daerah aktif Mataharinya hanya sekitar 25,3\%.

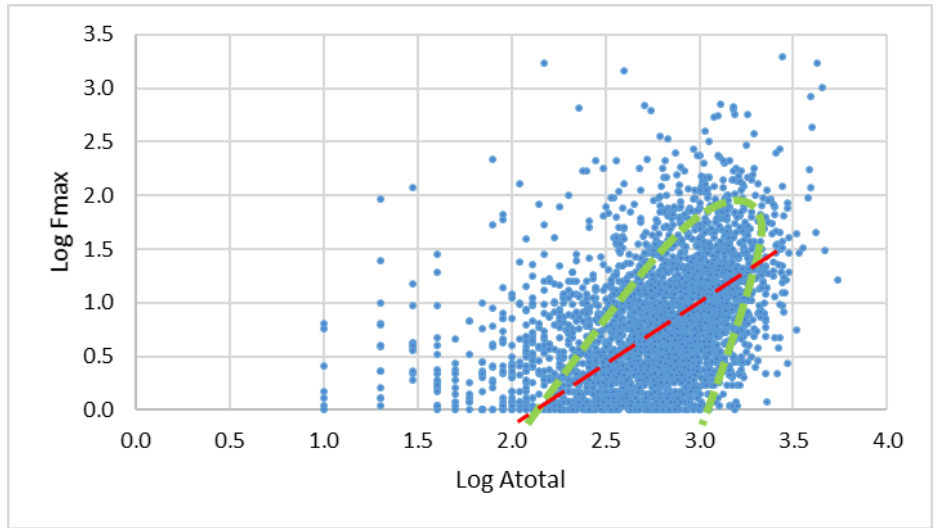

GAMBAR 6. Grafik hubungan antara log total luas daerah aktif dengan log flare maks. Garis hijau putus-putus merupakan batas daerah yang rapat dan garis merah putus-putus merupakan gradien garis yang terbentuk

\section{PENUTUP}

Total luas daerah aktif dengan kelas Zurich disimpulkan memiliki hubungan yang linier, meskipun bintik Matahari dengan luas daerah aktif yang tidak seberapa, tetap dapat menghasilkan flare besar. Luas daerah aktif Matahari yang kecil lebih sering muncul dibandingkan luas daerah aktif yang besar, yaitu dalam rentang luas $10-15,85 \mu \mathrm{H}$, dengan distribusi yang dapat dihampiri dengan suatu fungsi eksponensial. Pola perubahan harian luas daerah aktif Matahari yang diperoleh yaitu kelas perubahan "Tetap". Diperoleh pula adanya hubungan yang linier secara empiris antara total harian luas daerah aktif Matahari dengan flare maksimum dengan nilai korelasi dan determinasinya sedang dan rendah.

\section{UCAPAN TERIMAKASIH}

Terimakasih Penulis ucapkan kepada NOAA dan SILSO - SIDC yang telah menyediakan data secara publik untuk berlangsungnya penelitian ini.

\section{REFERENCES}

[1] T. Pettauer and P. N. Brandt, "On Novel Methods to Determine Areas of Sunspots from Photoheliograms," in Solar Physics, vol. 175, no. 1, pp. 197-203, 1997.

[2] A. Hempelmann and W. Weber, "Correlation Between the Sunspot Number, the Total Solar Irradiance, and the Terrestrial Insolation," in Solar Physics, vol. 277, no. 2, pp. 417430, 2012.

[3] K. Lee, Y. J. Moon, K. S. Lee and H. Na, "Solar Flare Occurrence Rate and Probability in Terms of the Sunspot Classification Supplemented with Sunspot Area and its Changes," in Solar Physics, vol. 281, no. 2, pp. 639-650, 2012.

[4] K. Lee, Y. J. Moon and J. Y. Lee, "Forecast of a Daily Halo CME Occurrence Probability Depending on Class and Area Change of the Associated Sunspot," in Solar Physics, vol. 290, no. 6, pp. 1661-1669, 2015.

[5] R. Priyatikanto, "Evaluasi dan Prediksi Cuaca Antariksa Berdasarkan Perubahan Harian Indeks Aktivitas Matahari: SSN, F10.7, Fxray, dan Eflare," in Jurnal Sains Dirgantara, 
vol. 13, no. 1, pp. 37-46, 2015.

[6] I. Sammis, F. Tang and H. Zirin, "The Dependence Of Large Flare Occurrence On The Magnetic Structure Of Sunspots," in The Astrophysical Journal, vol. 540, no. 1, pp. 583$587,2000$. 